\title{
Territorial Stigmatization, Gendered Racism and Young pÿPeople s Agency in a Multi-Ethnic School
}

\section{Keskinen, Suvi}

Routledge

2018

pÿKeskinen , S 2018 , Territorial Stigmatization, Gendered Racism and Young People s Agency in a Multi-Ethnic School . in T Shefer, J Hearn, K Ratele \& F Boonzaier (eds), Engaging Youth in Activism, Research, and Pedagogical Praxis : Transnational and Intersectional Perspectives on Gender, Sex, and Race . 1st edn, Routledge Critical Studies in Gender and Sexuality in Education , Routledge , London , pp. 235-248 . https://doi.org/10.4324/9781315270470-1

http://hdl.handle.net/10138/255643

https://doi.org/10.4324/9781315270470-14

other

acceptedVersion

Downloaded from Helda, University of Helsinki institutional repository.

This is an electronic reprint of the original article.

This reprint may differ from the original in pagination and typographic detail.

Please cite the original version. 


\section{Territorial stigmatisation, gendered racism and young people's agency in a multi-ethnic school}

Suvi Keskinen

\section{Introduction}

Young people belonging to racialised minorities are at the centre of many problem filled discourses and moral panics in today's Europe. Minority youth are mentioned as a problem in public discussions of school drop-out and unemployment, the hijab and other Muslim women's bodily coverage, and riots and other disturbances in the minority-dense impoverished residence areas. The problems have often been located in minority families and the generational relations within these. Scholars have identified a 'crisis of multiculturalism' discourse that has characterised media and politics in several European countries during the last decade (Grillo, 2007; Lentin \& Titley, 2011; Vertovec \& Wessendorf, 2010). Within this discourse, circulating across national borders with only a few local modifications, especially Muslims and non-western minorities are claimed to have established 'parallel societies' with illiberal cultures, oppression of women and fertile ground for terrorism, a process allegedly made possible by the politically correct and naïve proponents of multiculturalism among the (white majority) elite. As a result, racialised minorities have been confronted with increasing scrutiny and demands on integration and assimilation by leading politicians and authorities.

In this chapter, I will look at how minority young people search for ways to build their lives, gain respectability and perform agency in a societal context characterised by the previously mentioned processes. The focus will be on the gendered and sexualised aspects of racism, as they are lived out by young people in a multi-ethnic suburb in Finland, and the different strategies they develop to question, ignore and disturb such practices. The nodal point through which the societal discourses enter into the lives of the young people is the locality in which they live, a suburb situated at the margins of a city in Southern Finland and known for its large share of rental housing, low income level and - most of all - a high number of migrants and descendants.

Finland, like many nation-states in Europe today, has experienced a rise of neonationalism and racist activities in politics and social media in recent years. The anti-immigration and racist activities were first developed in social media and a couple of small ultranationalist organisations, but in the municipal elections 2008 several of these activists gained positions as local councillors and in the Parliamentary elections of 2011 the right-wing populist True Finns party gained a considerable increase of support resulting in $19 \%$ of the votes (Horsti \& Nikunen, 2013; Keskinen, Rastas \& Tuori, 2009). While anti-immigration and racist activities have now become more organised in the political and media sphere, racism is by no means a new phenomenon in the Finnish society, nor is it exclusive to right-wing populists. Several studies have shown that everyday racism (Essed, 1991) is part of the life of growing up as a non-white or ethnicised minority child and young person in Finland (e.g. Rastas, 2005). Surveys of the whole population (Jaakkola, 2009) and authorities (Pitkänen, 2008) 
show that a considerable share of the respondents are reluctant towards migrants who come from non-western countries and some host clearly racist views. The unemployment rate of migrants and their children is clearly higher than that of the majority population and studies have shown that recruitment barriers exist both in regards to the recognition of qualifications (Nieminen, 2011) and a racialised selection of candidates to open positions (Ahmad, 2005). Low income and poverty are more common among migrant families than among the majority population; such conditions also seem to persist in time and characterise even the generation born in Finland (Laitinen, Jukarainen \& Broberg, 2016, p. 31-32) Thus, patterns of structural racism are embedded in the Finnish society, although seldom discussed in these terms.

\section{Racism, gender and sexuality in the Nordic context}

In Finland and the other Nordic countries, racism and colonialism are commonly viewed as marginal and even non-issues due to the fact that the countries did not have as many colonies outside Europe as did former empires like the UK, France or the Netherlands. There is a widespread ignorance and denial of racism and the racial histories within the Nordic region (Hübinette \& Lundström, 2014; Isaksson \& Jokisalo, 1999). For a long time, the countries have claimed a 'bystander position' in relation to colonialism and denied the widespread participation in colonial endeavours they held through trade relations, slave trade, missionary work, scientific knowledge production and circulation of colonial representations (see Keskinen, 2014, 472-473). In contrast to such 'epistemologies of ignorance' (Mills, 1997), critical scholars have introduced concepts such as 'colonial complicity' (Vuorela, 2009) to discuss the position of the Nordic countries in the (post)colonial world order. The concept is perhaps especially suitable to describe the position of Finland, since unlike Sweden and Denmark the country never had any colonies and was, in fact, under the rule of Sweden and Russia for a long period. Nevertheless, studies have shown that the representations of for example Africans followed the same colonial imaginaries as in the other European countries (Kaartinen, 2004; Rastas, 2012). The ignorance of racial histories and racist namings has been challenged during recent decades, when the settlement of migrants from non-western countries has made it clear that terms like the n-word ${ }^{1}$ are not acceptable or neutral, as is often claimed.

In addition to the ignorance and denial of racial histories, characteristic for the forms of racism that have developed in Finland and the Nordic region overall is an emphasis on gender and sexuality. Avtar Brah uses the concept 'gendered racism' to grasp how racism takes gendered forms both building on and producing gendered differentiations. Departing from the idea that the notion of race "is essentially an essentialist narrative of sexualised difference" (Brah, 1996, p. 156), it is possible to understand why the creation of racialised difference concentrates around common origin, blood, kinship and home (cf. Keskinen, 2013). Provided that the Finnish national identity is strongly tied to a self-evident whiteness, we can see that the reproduction of the racially marked nation centres on white womanhood and heterosexual

\footnotetext{
${ }^{1}$ The n-word refers to the derogatory term used of black people that was developed during the history of slavery and colonialism.
} 
family. Those excluded from the dominant understandings of the nation-state are also racialised differently depending on the gendered attributes they are given. Moreover, both the racial and gendered categorisations are based on naturalising discourses, in which perceived differences are inscribed to the body and thus strengthen the idea that such differences are profoundly 'natural'.

In the Nordic countries, gender equality and sexual freedom have become boundary markers through which the white majorities can claim being civilised and progressive as opposed to the 'bad patriarchies' seen to characterise the racialised minorities (e.g. de los Reyes, Molina \& Mulinari, 2002; Keskinen, Tuori, Irni \& Mulinari, 2009). Some of the central ways that such distinctions have taken place in the recent decade are public debates on honour-related violence and Muslim women's headscarves and full coverage (e.g. Keskinen, 2009;

Rosenberger \& Sauer, 2012). Discussions on honour-related violence and social control in minority families have portrayed the patriarchal cultures of especially Muslims and migrants from the Middle-East as at the roots of women's oppression and gendered violence in families, while simultaneously describing the white majority as gender equal and normalising violent behaviour among these families (e.g. Keskinen, 2012; Carbin, 2014). Moreover, tolerance of sexual minorities has become a mode of progressive self-identification for the liberal elite and middle-class, as well as a building block of homonationalist (Puar, 2007) projects that exclude non-white and Muslim minorities from the national community on basis of their alleged homophobia.

\section{Data and method}

The data was collected in a research project that sought to examine young people's lives in multicultural contexts from an intersectional feminist perspective (1). Young people aged 1416 years were recruited to interviews through approaching them at a school in a multi-ethnic residential area. In order not to single out minority students nor to restrict 'multicultural' only to those treated as 'others' in the Finnish society, as many previous studies have done, all students in the class were asked about their willingness to participate in the interviews. The youths could also choose whether they wanted to be interviewed individually or with a friend, since other studies have shown that teenagers do not always feel comfortable in an interview situation. The data consists of 24 interviews with 43 young people. The school is located in a suburb that hosts one of the highest percentages of inhabitants with migration experiences and their descendants in Finland. At the school, where the interviews were conducted, approximately 60 percentages of the students have transnational roots.

While the data consists of interviews with young people with a range of ethnicised and racialised identifications, including white majority Finns, I will in this chapter only examine the interviews with young people who have one or two parents born outside Finland. Since the young people are differently positioned in relation to gendered racism and racialising discourses overall, it is not possible to explore in detail all interviews within the scope of one chapter. Thus, I have chosen to focus on the young persons who are presented as the 
racialised 'others' in the dominant discourses. The data consists of interviews with 26 young persons, out of which 12 are girls and 14 boys. Their family background can be located in countries such as Iraq, Iran, Afghanistan, Russia, Romania, Vietnam, former Yugoslavia, Somalia, Turkey, Sudan, and Zambia. Several young persons identified as Kurds, instead of the nation-states from which they or their parents had migrated.

In the interviews, the following topics were discussed: peer relations, school environment, residential area, experiences of racism, appearance, media consumption, family, dating/marriage and sex, and future plans. The choice to approach all young people in the classes proved successful and resulted in a high number of interviews, with over half of the students in the classes participating. The interviews were conducted in a building for afterschool activities. Despite this, the closeness to the school and its institutional context may have affected the interview environment. Overall the young people were fairly open about their views and lives, yet the fact that they were only interviewed once and the thematic list was long meant that the discussions seldom dug very deep into a single topic. However, several young people expressed their satisfaction of having had the chance to clear their thoughts through the interview and were pleased to contribute with their views.

The interviews were transcribed and coded with the help of the computer assisted programme Atlas.ti. I coded the interview material to locate sections in which gender and racism were discussed, cutting across the themes of the interview scheme. The analysis method combined thematic analysis with tools developed in discursive psychology (Jørgensen \& Phillips, 2002, 96-134). The latter were used to identify how young people's agency and identity negotiations took place in the data. This kind of thematic reading has been combined with a more holistic reading of the whole interviews, in order to locate the central logic in the interviews and the way that for example the reputation of the residential area is connected to stories of respectability and heterosexuality. Gendered racism was not conceptualised as such in the interviews, nor did the interviewees necessarily speak about racism in connection to the events discussed here; instead, the interpretation of what counts as gendered racism is based on my theoretical understanding.

\section{The suburb with 'the bad reputation'}

The residential area which we studied is well known in Finland, even for people who have never set their foot in the area. It is one of the few residential areas in the country that has a reputation similar to those of the migrant-dense areas in other European countries, such as the banlieus in France (Fassin, 2013), the areas with large Turkish communities in Germany (Stehle, 2013) and the racialised suburbs in Sweden (Sernhede, 2011). In the public images of the area the local and global intertwine, leading thoughts to a suburb with grim concrete buildings and inhabitants who have arrived from around the globe, a large share of them from non-western countries. Thus, place is understood through the social relations that characterise it, but even more so through the meanings attached to it. Loïs Wacquant (2008) uses the concept 'territorial stigmatisation' to discuss the perception of socio-economically 
disadvantaged residential areas in which racialised minorities constitute the majority of the inhabitants. Wacquant's contribution lies in the emphasis he gives to economic and political processes, such as neoliberal globalisation, restructuration of the labour market and welfare state, and local and national policies, when examining the racialised suburbs. The concept 'territorial stigmatisation' also rightly points to the importance of media coverage in the establishment of othering narratives of the residence areas where ethnic/racial and class bound inequalities merge. However, his analysis focuses on class and is clearly weaker when it comes to exploring the role of racialisation and ethinicisation in the processes of 'territorial stigmatisation'.

Public discourses shape understandings of the multiethnic residential areas and have concrete effects on the lives of people who live there. For example, living in a stigmatised area may provide problems when seeking employment, since the images of the residential area can function as an exclusionary factor when recruiters select candidates for a position (Sernhede, 2011). Even if such clear links between the negative view of the residential area and the treatment of its inhabitants would not take place, the residents' views of the area and people living there are affected by the stigma.

In the interviews, nearly all of the young people referred to the reputation of their residential area. Many of them called it an area with 'a lot of refugees', whereas some talked about a place with 'many immigrants'. The fact that a large part of the young people connected the reputation of the area with 'refugees' is symptomatic to the racialisation processes that take place in the Finnish society with respect to migration from countries in Africa, Middle-East and Asia. In such imaginaries, 'refugees' stand for poor migrants with low education and cultures that are perceived to be 'different' (cf. Keskinen, 2011). Even the category of 'immigrant' has been identified as a racialising term that is seldom used for white, middleclass migrants from Europe or the US (Leinonen 2012; Rastas, 2005). Quite rightly, some of the residents in the area have a family background in non-western countries, but among the inhabitants a large share also consist of white majority Finns and migrants from Russia, Estonia and other European countries. The fact that these groups do not figure very strongly in the public images of the suburb is a result of racialisation processes that establish the central difference as that of the white/European and the non-white/non-European.

Sometime before the interviews were conducted, a TV-programme on 'residential areas with a bad reputation' had been showed by a broadcasting company in Finland. The journalists had visited residential areas all over the world, each of which had a reputation connected to criminality, social unrest and racialised inhabitants. The visited areas were described as areas 'which tourist guides advice you to avoid' and included for example a black township in South-Africa, a French banlieu and one of the racialised suburbs in Sweden. Among the visited places was also the suburb in which our study was conducted. The young informants were mostly angry and disappointed at the way their neighbourhoods were presented in the programme. The focus on criminality and social unrest seemed exaggerated to the young people, many of whom confronted this image by stating that the area was peaceful and that they were not afraid when moving around in the area. They were thus talking back (hooks, 
1989), criticising and challenging the racialising ideas of their area and themselves that are circulating in the media and the public sphere.

People have a bit misleading thoughts about this area, thinking that there are many immigrants here and a long time ago, like in the 1990s, some violent crimes took place... That must make the bad reputation, and some houses look a bit rundown and so... Like you read the book very much by the cover, people who don't live here can't really understand... you know, if you just hear rumours that somebody was beaten here or another was killed there or that there are so many immigrants here, then you actually don't know, you just build your view on some rumours.

Other young people accepted to a certain extent the interpretation of their area as unsafe and some stated that they would like to move away from the area, to a cosier place where one need not think about being called names or of being attacked by somebody. It seems, however, that the threat and name calling the youth were referring to was largely connected to the substance abusers who occupied some of the central areas of the suburb. To the extent that this threat was racialised by our informants, it was mainly connected to white majority Finns who were drunk or on drugs and behaved in a threatening way. Some also mentioned minority youth who had a criminal record as a source of discomfort and distress, referring to their own or friends' experiences of being robbed or aggressively confronted in the area. In some of these accounts, the internalising of the stigmatising views in the media and other dominant representations of the area was present. Some young people, while belonging to racialised minorities, distanced themselves from what they called the 'immigrants' and the negative traits that were connected to these groups in public. Following Frantz Fanon's (1986) idea of internalising the perspective of the colonist, we can interpret these situations as the young people adopting the dominant racialising perspective of themselves and the people around them, yet seeking to establish a respectable self-image by distancing from this image and presenting oneself as different from the 'others'.

\section{Young men's struggles for respectability}

The representations of the area and its inhabitants were also highly gendered. As in representations of other stigmatised and racialised residence areas (e.g. Fassin, 2013; Stehle, 2013), the threat and source of insecurity was often located in young men's bodies. If gendered racism portrays young non-white women as victims of their families' violence and control, in need of saviour by the majority society (e.g. Keskinen, 2009), young non-white men are in such discourses presented with potential for violence and rioting. In the TVprogramme on the area we studied, the journalists discussed vandalism in the neighbourhood and asked some of the young men they interviewed whether riots could occur in their area, as they had in other European suburbs with large minority populations. Since no riots, burning of cars or other activities linked to demonstrations in the racialised suburbs elsewhere had occurred in the area of our study, clearly the journalists' questions were related to racialised expectations of 'similar events' taking place where minority youth lived. 
The stories of the young people living in the area, on the other hand, show a nuanced understanding of the risks of criminality and marginalisation in their neighbourhoods. The young men and their families were aware that for example drug selling was taking place in the area and some mentioned avoiding close contacts to people who were connected to such activities. One of the interviewed boys told how he was mixed up with another black guy selling drugs in the area and how his parents became worried about him. The parents were perhaps not so concerned about him becoming involved in drug business, after all they knew their son and trusted him, according to the interviewee. But the risk of being caught and questioned by the police seemed to be worrying as such. For a young black man from a suburb 'with a bad reputation' to be involved with the police is a risk as such - of being labelled, risking disrespectful treatment by the police and affecting the feeling of safety of the young person.

One strategy to counteract the risks of criminality and marginalisation, as well as the racialised public images of young men in the suburb was to focus on school achievements and seek to gain a respectable image. Ahmed (A), whose parents had migrated from Somalia, said that he chose his friends so as to avoid those with bad habits who might lead him into trouble.

A: I don't move around with many in my class because they smoke tobacco and everything, I don't like such people.

$\mathrm{I}: \mathrm{OK}$, in your class... do all the boys?

A: Well nearly over half of them smoke $[\ldots]$

I: What kinds of advice or guidelines have your parents given you?

A: Well, like... to avoid people who are not behaving well, not behaving well, and then also to avoid ending up yourself in troubles, avoiding to bully somebody, or then you may end up bullied yourself, and like focus on your own studies and try to respect the class as much as you can and respect teachers and other adults.

Ahmed was speaking about choosing to achieve well at school and aiming for success in life, which at the same time required distancing from the problematic 'others' - the racialised image of the troublemaking young man from the stigmatised suburb but also the individuals in the neighbourhood that might lead to fulfilling such prophesies. It is important to understand that while the representations of the area are racialising and thus tend to essentialise differences, the socio-economic hardships and the racialisation in the labour market do provide risks of marginalisation for the young people in the suburbs. Thus their strategies do not only centre on 'talking back' against specific representations of their area and themselves, but also searching for ways to deal with the materialities of marginalisation and structural racism. The problem with this may be, as in the case of Ahmed, that the young persons are pushed to adopt individualist strategies of success that fit well into the neoliberal rationalities of the current era (Goldberg, 2009) but simultaneously require a distancing of other young people positioned as the racialised 'others'. 
Not all the young men we interviewed distanced themselves from their peer-group or sought for school achievement as a way to combat risks of marginalisation. While many had parents who encouraged them to study and do well at school, several of the boys expressed hesitance towards long studies and felt more comfortable with the idea of continuing at vocational school or starting to work. Even the future plans of these young men consisted of ordinary life involving work and family - that is, one strategy to confront and rewrite racialising images of young men in the suburbs was to call for the 'ordinary' as a way of becoming respectable in one's own and the others' eyes.

\section{Gendered racism and sexual reputation}

Encountering stigmatisation and gendered racism meant somewhat different things for the young women than the young men in the suburb. The representations of minority girls circulating in the public sphere centre on gendered and sexualised notions of patriarchal oppression and being located 'between two cultures' (Honkasalo, 2013). Indeed, the young women in our interviews discussed reputation to some extent in relation to sexuality. But many of them also saw reputation as related to being a good friend, trustworthy and taking into account others. It was not self-evident that when the girls were asked about good vs. bad reputation they were referring to sexuality or sexual moral. Good reputation seemed to be as much about general ethics on how to behave towards others and be part of the group (of friends or class mates).

Neither is the connection of sexuality to reputation by no means restricted to racialised minorities: feminist research has convincingly shown that the social control of young women's sexual reputation is a central part of the gender order in most societies (e.g. Honkatukia, 1999; Lees, 1998). Concomitantly, the most explicit way that sexual reputation was discussed in our data was related to an incident in which a photo of a young woman's naked body was spread through mobile phones to a large group of school mates (Honkatukia \& Keskinen, in press). Some of the young women told about this incident, expressing both disgust at the (white majority) girl who exposed herself in such a way in a photo and at the school mates who distributed the photo among the students. This act of symbolic violence among the group of young people crossed all kinds of ethnicised and racialised boundaries: it seemed to involve both minority and majority youth in the multi-ethnic school. As such, it was also a powerful reminder for the girls of what could happen to them, if they were not careful with whom they engaged in intimate situations.

Many of the young women also criticised double-standards for girls and boys in relation to sexual behaviour. They argued against the injustice of young men receiving a positive reputation among peers when being the 'player' who dated many girls, while young women were not allowed to have affairs or else were accused of loose morals. Questioning the gendered division of sexual morality was thus one common strategy for the girls to resist the gendered order in their local environment. It also shows that young minority women are not the powerless victims they are often portrayed as by the white majority society. 
One of the strategies that minority young women used was the ridiculing and carnivalising of sexualised normativity. Two young women, Nasima (N) with parents from Afghanistan and Elena (E) with parents from Russia, made a total farce about the pair interview they participated in. They mocked each other and, in my interpretation, also the research that addressed issues of young people and multiculturalism. Playing with two racialising discourses - one featuring Russian women as prostitutes and the other portraying Muslim girls as married away at an early age and beaten by their parents - the girls challenged each other into a duel reminiscent of a rap battle, the effort of which is to verbally compete and outdo the opponent. The fact that the girls were friends and chose to participate in the interview together shows that they were not hostile towards each other but playing with the discursive resources available for them. Through the carnivalising of sexual morality they turned around power relations making them laughable, exaggerating the stereotypes so that they became ridiculous and by doing so also disturbed dominant ideas of minority sexualities.

$\mathrm{N}$ : She is Russian herself and insults Russians for being prostitutes, all of them.

E: I do really hate Russians a bit. But I am one myself.

$\mathrm{N}$ : Because Russia has a reputation that the girls are terrible prostitutes. [...]

E: In Afghanistan they beat children, it really goes beyond my understanding. My mom has never beaten...

N: Sure! And in Russia they sell their bodies all the time. So don't start a fight now... $[\ldots]$

N: I'm 15, soon I'll be 16, and I'm not at all thinking about getting married.

E: She has been married for the first time when she was 12 years.

$\mathrm{N}$ : No, these people think that I will marry as very young, but I won't.

E: Well with that face you can't get anyone either.

$\mathrm{N}$ : OK, but luckily with your face you can get such a huge number.

Elena's reference to being part of the group (Russians) that she mocks and 'hates', but at the same time is part of, could be interpreted as a passing joke. On the other hand, it could also be a reflection of the internalised racism that was discussed in relation to the reputation of the residential area and distancing from the perceived 'problematic others'. Perhaps Elena raises the question of what it is to be a Russian, and especially a young woman categorised as Russian, and how to situate herself towards these racialising images. Instead of right away distancing herself from the category of the 'Russian woman' she plays with the identification and holds on to it, wondering whether to claim it as her own or not. 
Nasima, on the other hand, does take up the Afghan identity but argues that she will not follow the behaviour expected of her in the racialising discourse: she is not going to be married away at a very young age and she will be the one to decide what happens in her life. Also by talking in sexually explicit ways she is challenging the stereotype of the oppressed minority girl and instead, through her verbal acrobatics, presents herself as a fearless offensive actor.

Instead of presenting themselves as respectable young women, Nasima and Elena do the opposite: they ridicule the idea of needing to be a respectable woman. Yet, the fact that they engage so whole heartedly with this image shows that it and the racialising discourses that create it bear at least some relevance in their lives. As in the case of the young minority men, discussed earlier, the young women are not only questioning the racialising discourses of themselves (as oppressed and passive victims), but also struggling with a gendered social order that provides to some extent different conditions for their lives than for the young men.

\section{Conclusions}

This chapter has sought to examine how gendered racism shapes the conditions in which racialised minority youth live their everyday lives and how the young people challenge, ignore and disturb such discourses and practices. Feminist analyses on gendered racism have often focused only on racialised minority women and the construction of femininities, but I argue that it is as important to examine gendered racism in connection to minority young men and racialised masculinities. Thus, I have examined here the (somewhat) different forms that gendered racism and its challenging take depending on whether it addresses young men or women(2). Gendered racism portrays young minority men as aggressive and out of control, while young women are defined in relation to their sexualised bodies - their sexual reputation shifting from the 'too loose' to the 'too strict', in comparison to the white norm.

I have argued that a central element in how gendered racism affects the young people's everyday lives is through the residential area in which they live and go to school. Territorial stigmatisation creates notions of dangerous areas at the margins of the civilised society. The strategies minority youth used when confronted with such images of their area and themselves were varied. They could explicitly 'talk back' and question for example the stigmatising narratives of their neighbourhoods and produce alternative descriptions of the area. They also presented themselves as respectable young persons who sought to educate themselves and find good jobs, a strategy especially important for young minority men who encountered notions of themselves as future criminals and unemployed 'losers'. On the other hand, such counter-strategies could lead to distancing from peers and other racialised minority persons, with the effect of developing individualist strategies and creating loneliness. As pointed out, there were also elements of an internalising of the racist images, which can result in psychic distress.

Moreover, the young minority women's strategies towards gendered racism also included 'talking back' and questioning especially gendered and racialised discourses of sexual 
morality. The young women did not accept the way they were presented as passive victims, but struggled to make their views heard, carnivalised and ridiculed racialising discourses, and reflected on their identifications. They also to some extent ignored the definitions of respectability that were created around sexuality and instead discussed ethical concerns of how to be a good person and part of the (youth) group.

Young people have several ways of responding to and challenging gendered racism. Yet, the structural inequalities related to 'race', ethnicity and class that seem to persist in the Finnish society affect their possibilities and choices in life, as well as impact on their everyday experiences. Thus, the struggle against gendered racism is not only about changing certain stereotypes but involves a wide range of social, economic and cultural processes.

\section{Endnotes}

1. The project Generational negotiations, social control and gendered sexualities was funded by the Academy of Finland (grant 261187) in 2012-2016. The writing of this chapter has also been enabled by the Academy of Finland grant 275032.

2. I acknowledge the heteronormative basis of focusing on 'men and women' and without doubt a discussion on non-normative sexualities and trans questions in the context of gendered racism and respectability would have been in place. Within the scope of this article it has, however, not been possible to discuss all these perspectives.

\section{References}

Ahmad, A. (2005). Getting a Job in Finland. The Social Networks of Immigrants from the Indian Subcontinent in the Helsinki Metropolitan Labour Market. Helsinki, Finland: University of Helsinki.

Brah, A. (1996). Cartographies of Diaspora. London, UK: Routledge.

Carbin, M. (2014). The Requirement to Speak: Victim Stories in Swedish Policies Against Honour-related Violence. Women's Studies International Forum, 46, 107-114.

de los Reyes, P., Molina, I., \& Mulinari, D. (2002). Maktens (o)lika förklädnader. Kön, klass \& etnicitet i det postkoloniala Sverige. Stockholm, Sweden: Atlas.

de los Reyes, P., \& Mulinari, D. (2005). Intersektionalitet. Lund: Liber.

Essed, P. (1991). Understanding Everyday Racism: An Interdisciplinary Theory. Newbury Park: SAGE.

Fanon, F. (1986). Black Skin, White Masks. London, UK: Pluto Press. 
Fassin, D. (2013). Enforcing Order: An Ethnography of Urban Policing. Cambridge, UK: Polity Press.

Goldberg, D.T. (2009). The Threat of Race. Malden: Wiley \& Blackwell.

Grillo, R. (2007). An Excess of Alterity? Debating Difference in a Multicultural Society. Ethnic and Racial Studies, 30 (6), 979-998.

Honkasalo, V. (2013). 'Save the Girls!' Gender Equality and Multiculturalism in Finnish Youth Work Contexts. Journal of Girlhood Studies, 6(2), 47-64.

Honkatukia, P. (1999). Gender, Social Identity and Delinquent Behaviour. Retfaerd. 22 (3), 41-52.

Honkatukia, P., \& Keskinen, S. (in press). The Social Control of Young Women's Clothing and Bodies: A Perspective of Differences on Racialization and Sexualization. Ethnicities hooks, bell. (1989). Talking Back: Thinking Feminist, Thinking Black. Boston: South End Press.

Horsti, K., \& Nikunen, K. (2013). Ethics of Hospitality in Changing Journalism: The Response to the Rise of the Anti-Immigrant Movement in Finnish Media Publicity. European Journal of Cultural Studies, 16 (4), 489-504.

Hübinette, T., \& Lundström, C. (2014). Three Phases of Hegemonic Whiteness: Understanding Racial Temporalities in Sweden. Social Identities: Journal for the Study of Race, Nation and Culture, 20 (6), 423-437.

Isaksson, P. \& Jokisalo, J. (1999). Kallonmittaajia ja skinejä. Helsinki, Finland: Like.

Jaakkola, M. (2009). Maahanmuuttajat suomalaisten näkökulmasta. Asennemuutokset 19872007. Helsinki: Helsingin kaupungin tietokeskus.

Kaartinen, M. (2004). Neekerikammo. Kirjoituksia vieraan pelosta. K \& H. Turku, Finland: University of Turku.

Keskinen, S. (2009). Honour-related violence and Nordic nation-building. In S. Keskinen, S. Tuori, S. Irni, \& D. Mulinari (Eds), Complying with colonialism: Gender, race and ethnicity in the Nordic region (pp. 257-272). Farnham, UK: Ashgate.

Keskinen, S. (2011). Troublesome Differences - Dealing with Gendered Violence, Ethnicity and Race in the Finnish Welfare State. Journal of Scandinavian Studies in Criminology and Crime Prevention, 12(2), 153-172.

Keskinen, S. (2012). Limits to speech? The Racialised Politics of Gendered Violence in Denmark and Finland. Journal of Intercultural Studies, 33(3), 261-274. 
Keskinen, S. (2013). Anti-feminism and White Identity Politics - Political Antagonisms in Radical Right-wing Populist and Anti-immigration Rhetoric in Finland. Nordic Journal of Migration Research, 3(4), 225-232.

Keskinen, S. (2014). Re-constructing the Peaceful Nation. Negotiating Meanings of Whiteness, Immigration and Islam in Media and Politics after a Shopping Mall Shooting. Social Identities: Journal for the Study of Race, Nation and Culture, 20(6), 471-485.

Keskinen, S., Rastas, A., \& Tuori, S. (2009). En ole rasisti mutta... Maahanmuutosta, monikulttuurisuudesta ja kritiikistä. Tampere, Finland: Vastapaino.

Keskinen, S., Tuori, S., Irni, S., \& Mulinari, D. (2009). Complying with Colonialism. Gender, Race and Ethnicity in the Nordic Region. Farnham, UK: Ashgate.

Laitinen, K., Jukarainen, P., \& Broberg, H. (2016) Maahanmuutto \& turvallisuus - arvioita nykytilasta ja ennusteita tulevaisuudelle. Valtioneuvoston tutkimus- ja selvitystoiminnan julkaisusarja 7/2016. Helsinki, Finland: Valtioneuvosto.

Leinonen, J. (2012). 'Invisible immigrants, visible expats? Americans in Finnish discourses on immigration and internationalization'. Nordic Journal of Migration Research, 2 (2), 213223.

Lentin, A. \& Titley, G. (2011). The Crises of Multiculturalism. London, UK: Zed Books.

Mills, C.W. (1997). The Racial Contract. Ithaca: Cornell University Press.

Nieminen, S. (2011). Kuulumisen politiikka. Maahanmuuttajasairaanhoitajat, ammattikuntaan sisäänpääsy ja toimijuuden ehdot. Acta Universitatis Tamperensis 1616. Tampere, Finland: University of Tampere.

Pitkänen, P. (2008). Ethnic and Cultural Diversity in Public Sector Work in Finland. Finnish Journal of Ethnicity and Migration, 3 (3), 32-41.

Puar, J. (2007). Terrorist Assemblages: Homonationalism in Queer Times. Durham: Duke University Press.

Rastas, A. (2005). Racialising Categorization among Young People in Finland. YOUNGNordic Journal of Youth Research, 13 (2), 147-166.

Rastas, A. (2012). Reading History through Finnish Exceptionalism. In K. Loftsdottír, \& L. Jensen (Eds), Whiteness and Postcolonialism in the Nordic Region. Exceptionalism, Migrant Others and National Identities (pp. 89-103). Farnham, UK: Ashgate.

Rosenberger, S., \& Sauer, B. (2012). Framing and Regulating the Veil. New York: Routledge.

Sernhede, O. (2011). School, Youth Culture and Territorial Stigmatization in Swedish Metropolitan Districts. YOUNG - Nordic Journal of Youth Studies, 19 (2), 159-180. 
Stehle, M. (2013). 'White Ghettos': The 'Crisis of Multiculturalism' in Post-unification Germany. European Journal of Cultural Studies, 15 (2), 167-181.

Vertovec, S., \& Wessendorf, S. (2010). The Multiculturalism Backlash. London, UK:

Routledge.

Vuorela, U. (2009). Colonial Complicity: The 'Postcolonial' in a Nordic Context. In S.

Keskinen, S. Tuori, S. Irni, \& D. Mulinari (Eds), Complying with Colonialism. Gender, Race and Ethnicity in the Nordic Region (pp. 19-33). Farnham, UK: Ashgate.

Wacquant, L. (2008). Urban Outcasts. A Comparative Sociology of Advanced Marginality. Cambridge, UK: Polity. 